\title{
メディカルフィットネスプログラム選定方式一第二報一 一プログラム選定手順とその応用一
}

山田 敏一1) 大村 憲治 ${ }^{1)}$ 田辺 親男 ${ }^{21}$ 坂崎 富夫 ${ }^{3)}$

\section{目 的}

メディカルフィットネスとは, 医学的情報管理（肉 体面, 精神面の医学的デー夕) に基づいてフィットネ スを行うことである。メディカルフィットネスプログ ラム選定をコンピュータを利用して自動化したので報 告する。

\section{方 法}

メディカルフィットネスプログラム選定の基本的な 流れは, (1)「健康診断」, (2)「体力測定」, (3)「(1)(2)の 結果を基にプログラム選定」，(4「当日の健康状況等に よるプログラム修正」となっている。この中で, コン ピュータを利用してメディカルフィットネスプログラ 么選定を自動化すると次のような手順となる。まず, 健康診断, 体力測定の結果をオンラインでコンピュー 夕に取り込み，端末画面の指示によりその結果を解析 して最適な推奨フィットネスプログラムを作成する。 次に, 端末画面で当日の健康状況等よりフィットネス プログラム修正を行った後にプリントアウトする。

この中で健康診断，体力測定の結果を解析してフィ ットネスプログラムを選定する部分が繁雑な作業とな る。この部分を詳細に解説する。

1)フィットネスにとって重要な疾患の有無チェック (無ければ4)へ飛ぶ)

重要な疾患を定義した「結果情報マスター」に, 該当する疾患があるかチェックする。

2)疾患に適合した種目の選択・不適合種目の除外 疾患ごとにトレーニング種目の適・不適を定義し た「診断別基本トレーニングマスター」を読み取 り, 疾患に適合した種目の選択・不適合種目の除 外を行う。

3)疾患に適合した運動強度の設定

疾患ごとに運動強度を設定した「診断別基本トレ
ーニングマスター ( 2 ) 項で利用するマスターと同 じ)」を読み取り, 疾患に適した運動強度を設定す る。

4) 血圧等に異常值があった場合の運動強度の再設定 血圧等検查結果に異常值があった場合への対応と して，異常值に対応した運動強度を取れるように 条件式を「負荷強度条件式マスター」に設定する。 この条件式に該当した異常值があった場合，運動 強度が再設定される。

5)電図モニター指定等のコメント指示

検査結果によってはコメント指示が必要となる。 このため「負荷強度条件式マスター（4) 項で利用 するマスターと同じ)」にコメントとコメント出力 判定条件式を設定する。必要なコメントがあった 場合, この条件式よりコメント指示が画面に表示 される。

これらの手順をアルゴリズムに書き直しコンピュー 夕登録した。上記に示すように各ステップごとに随時 改良可能な表形式のマスターを定義し，マスターに必 要デー夕を登録することにより，アルゴリズムの繁雑 さの回避，医師自ら登録・改良できることによるメン テナンス性の向上を図った。

\section{結 論}

メディカルフィットネスプログラム選定をコンピュ 一夕を利用して自動化したことにより，医学的情報を 基にした安全・治療効果のあるプログラムを瞬時に選 定することができた。また，プログラム選定手順に汎 用性を持たせたことにより，医学的情報をより有効に 利用できるように医師自らが手順を登録・改良するこ とができた。

今後は, この選定手順を「将来の疾患の危険度判定 手順」等に応用する予定である。

\section{Medical Fitness Program Checked by Medical Exami- nation}

島津製作所 情報システム部 